\begin{tabular}{|c|c|c|c|}
\hline \multirow{2}{*}{ 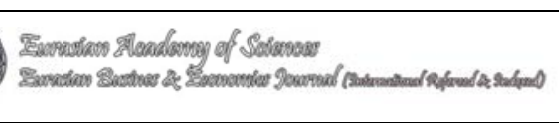 } & \multicolumn{3}{|c|}{$\begin{array}{c}\text { Eurasian Academy of Sciences } \\
\text { Eurasian Business \& Econormics Journal }\end{array}$} \\
\hline & 2015 & Volume:1 & S: $69-85$ \\
\hline \multicolumn{4}{|c|}{$\begin{array}{l}\text { Published Online April } 2015 \text { (http://busecon.eurasianacademy.org) } \\
\text { http://dx.doi.org/10.17740/eas.econ.2015-V1-03 }\end{array}$} \\
\hline
\end{tabular}

\title{
THE EFFECTS OF THE DEGREE OF INTERNATIONALIZATION ON BUSINESS PERFORMANCE: A FIELD STUDY
}

İbrahim AKBEN*, Salih YEŞIL **

\begin{tabular}{l}
\hline HASAN KALYONCU ÜNIVERSITESİ*, KAHRAMANMARAŞ SÜTÇÜ İMAM \\
ÜNIVERSITESI** \\
E-mail: ibrahimakben@gmail.com*, syes66@hotmail.com**
\end{tabular}

Copyright (C) 2015 İbrahim AKBEN, Salih YEŞIL. This is an open access article distributed under the Eurasian Academy of Sciences License, which permits unrestricted use, distribution, and reproduction in any medium, provided the original work is properly cited.

\begin{abstract}
The main purpose of this study is, firstly to reveal the impact of the degree of internationalization on business performance. For that purpose, the conceptual framework was formed by reviewing the national and international literature on the subject. Next, a field study was carried out on the companies ranked in Fortune 500 Turkey list. Research hypotheses were tested by analysing the obtained data with SPSS software. The results showed that degree of internationalization had a positive effect on subjective business performance and had a positive and partial effect on objective business performance.
\end{abstract}

Keywords: Internationalization, Degree of Internationalization, Business Performance, Subjective Business Performance, Objective Business Performance

JEL: F23, M16, L25

\section{Uluslararasılaşma Derecesinin İşletme Performansı Üzerindeki Etkileri: Bir Alan Çalışması ${ }^{1}$}

ÖZET: $\mathrm{Bu}$ çalışmanın amacı, işletmelerin uluslararasılaşma derecesinin işletme performanslarına olan etkilerini ortaya koymaktır. Bu amaçla öncelikle konuya ilişkin yerli ve yabancı literatür taranarak kavramsal çerçeve oluşturulmuştur. Daha sonra Fortune 500 Türkiye listesinde yer alan işletmeler üzerinde bir alan çalışması yapılmıştır. Elde edilen veriler SPSS programında analiz edilerek araştırmanın hipotezleri test edilmiştir. Çalışmanın sonucunda uluslararasılaşma derecesinin sübjektif işletme performansı üzerinde pozitif bir etkiye sahip olduğu, objektif işletme performansı üzerinde ise pozitif yönde ve kısmi bir etkiye sahip olduğu belirlenmiştir.

\footnotetext{
${ }^{1} \mathrm{Bu}$ makale "İşletmelerin Uluslararasılaşma Derecesini Etkileyen Faktörler, Uluslararasılaşma Derecesi ve Performans İlişkisi: Bir Alan Çalışması" başlıklı doktora tezinden türetilmiştir.
} 
Anahtar Kelimeler: Uluslararasılaşma, Uluslararasılaşma Derecesi, İşletme Performansı, Sübjektif İşletme Performansı, Objektif İşletme Performansı

\section{Giriş}

Küreselleşme süreci ve sürecin getirdiği değişim etkisi ve bunun bir sonucu olarak artan rekabet işletmeleri birçok rakiple hem ulusal hem de uluslararası alanda karşı karşıya getirmektedir. Bundan dolayı işletmeler rekabet güçlerini kaybetmemek ve ayakta kalabilmek için dinamik bir yapıya bürünerek sürekli olarak kendilerini yenilemek zorunda kalmaktadırlar. İşletmeler ulusal alanda, içerisinde bulundukları rekabet ortamından, uluslararasılaşarak kaçınmış olsalar da, uluslararası rekabet ortamında daha güçlü rakiplerle karşılaşmaları son derece sıradan bir durumdur. Bu durum da işletmelerin performanslarını ister istemez olumlu veya olumsuz şekilde etkilemektedir.

$\mathrm{Bu}$ çalışmanın odak noktasını uluslararasılaşma derecesi ve işletme performansı oluşturmaktadır. Uluslararasılaşma; "işletmelerin faaliyetlerini ulusal sınırların dışına yayması" şeklinde tanımlanırken (Erkutlu ve Eryiğit, 2001: 150). Uluslararasılaşma derecesi (DOI) ise bir işletmenin belirli bir zaman diliminde uluslararası pazarlara olan ilgisinin bir resmini vermeye çalışan yapısal bir indikatördür (Rieck ve diğerleri, 2004: 13). Bir işletmenin uluslararasılaşma derecesini hesaplamak için ise çalışmanın ilgili kısmında açıklanan ve Sullivan (1994) tarafından geliştirilen DOI INTS ölçeği kullanılmaktadır.

Literatürde bu çalışma ile ilgili olarak benzer sayılabilecek çalışmalar mevcuttur, literatürdeki bu çalışmalarda uluslararasılaşma derecesi (DOI) tek bir indeksle ve işletme performansı ise tek boyutlu olarak dar bir kapsamda ele alınarak analiz edilmiştir. Örneğin Daniels ve Bracker, (1989) çalışmasında uluslararasılaşma derecesi olarak yabancı satışların, toplam satışlara oranının (FSTS), işletme performansı olarak satışların geri dönüşü ve varlıkların geri dönüşü üzerindeki etkileri; Riahi ve Belkaoui, (1998) çalışmasında yabancı satışların toplam satışlara oranının (FSTS), ROA üzerindeki etkilerini; Thomas ve Eden, (2004) çalışmalarında yabancı satışların toplam satışlara oranı (FSTS) ve yabancı varlıkların toplam varlıklara oranının (FATA), ROA ve ROE üzerindeki etkilerini araştırmışlardır. Bu çalışma ise daha önceki çalışmalardan daha kapsamlı ve bazı farklılıklar içermektedir

$\mathrm{Bu}$ çalışma da ise daha önce yapılmış olan benzer çalışmalardan farkl11lkları şu şekilde siralanabilir:

- Uluslararasılaşma derecesinin beş indeksle (çoklu indeksle) birlikte değerlendirilmesi,

- İşletme performansının, hem sübjektif hem de objektif işletme performansı şeklinde iki boyutuyla birlikte ele alınması,

- $\quad$ Bu iki farkında ötesinde bu çalışmanın en önemli farkı, çalışmanın Türkiye'de yapılması ve geniş kapsamlı olarak gerçekleştirilmesidir.

\section{Uluslararasılaşma ve Uluslararasılaşma Derecesi}

Uluslararasılaşma (internationalization) terimini tam olarak açıklamalk oldukça zordur. İşletmelerin veya büyük grupların uluslararası faaliyetlerindeki dış hareketleri açıklamada uluslararasılaşma terimi kullanılmaktadır (Mutlu, 2008: 84). Bu genel kullanım sonucu şöyle bir tanım yapılabilir: "artan uluslararası faaliyetlere girme yöntemidir" (Lawrence ve Luostarinen, 1988; aktaran, Mutlu, 2008: 84). İşletmeler uluslararası pazarda yer almaya başladığında uluslararası nitelik kazanmış olmaktadır. Bu; ister ihracat yoluyla olsun, ister 
direkt yatırım ya da diğer uluslararasılaşma stratejileri biçiminde olsun fark etmemektedir (Erkutlu ve Eryiğit, 2001: 150). Uluslararasılaşma derecesi (DOI) ise bir işletmenin belirli bir zaman diliminde uluslararası pazarlara olan ilgisinin bir resmini vermeye çalışan yapısal bir indikatördür (Rieck ve diğerleri, 2004: 13). Uluslararasılaşma derecesi, işletme faaliyetleri içerisinde dış pazarlara yönelik olarak yapılan çalışmaların ağırlığının belirlenmesidir.

Bunun da tespit edilmesinde en basit yöntem, işletme gelirlerinin ne kadarlık kısmının yurtdışındaki faaliyetlerden geldiğinin anlaşılmasına dayanmaktadır (Cengiz ve diğerleri, 2007: 7). Uluslararasılaşma derecesinin ölçülmesinde Sullivan (2004) tarafından geliştirilen bazı indeksler birlikte kullanılmaktadır

Uluslararasılaşma derecesi ile ilgili olarak vurgulanması gereken temel nokta, işletme faaliyetleri içerisinde dış pazarlara yönelik olarak yapılan çalışmalarının ağırlığının belirlenmesidir (Cengiz ve diğerleri, 2007: 7). Bir işletmenin uluslararasslaşma derecesinin belirlenmesinde ne gibi bir yöntem kullanılacağ 1 da tartış1lması gereken bir konudur. Bunun için kullanılan en basit yöntem işletmenin dış satışlarının toplam satışlarına oranlanmasıdır. İşletmenin genel satışlarının içindeki dış satışlarının oranı ne kadar yüksekse işletmenin uluslararasılaşma derecesi de o kadar büyük olacaktır. Bu ölçümleme çok basit olmasına rağmen, işletmenin uluslararası faaliyetlerinin yapısı ve kapasitesi hakkında az bilgi vermek gibi bir dezavantaja sahiptir (Mutlu, 2008: 84). Bundan dolayı Sullivan (1994), uluslararasılaşma derecesinin hesaplanabilmesi için bir ölçek geliştirmiştir.

$\mathrm{Bu}$ ölçeğe göre uluslararasılaşma derecesi oranı, bir işletme için; 0,00 - 5,00 arasında bir değer alır ve buna göre;

$0,00=$ Uluslararasılaşma ile ilgisi yok,

$5,00=$ Uluslararasılaşma ile en üst düzeyde ilgili, anlamına gelmektedir.

Uluslararasılaşma derecesini hesaplamak için Sullivan (1994) tarafından geliştirilen DOI INTS $_{\text {S }}$ ölçeği kullanılmaktadır (Altıntaş ve Özdemir, 2006: 186). Bir uluslararası işletmenin uluslararasılaşma derecesi aşağıdaki formül kullanılarak hesaplanabilir (Sullivan, 1994: 335).

$\mathrm{DOI}_{\mathrm{INTS}}=\mathrm{FSTS}+\mathrm{FATA}+\mathrm{OSTS}+\mathrm{TMIE}+\mathrm{PDIO}$

$\mathrm{Bu}$ indekste yer alan parametreler şu şekilde açıklanmaktadır:

DOI: Degree of Internationalization; Uluslararasılaşma Derecesi, FSTS: Foreign Sales to Total Sales: Yabancı Satışlar / Toplam Satışlar oranı.

FATA: Foreign Assets to Total Assets: Yabancı Varlıkların Toplamı / Toplam Varlıklar. OSTS: Overseas Subsidiaries to Total Subsidiaries: Yabancı Şubelerin Sayısı / Toplam Şube Sayisı.

TMIE: Top Manager's International Experience: Tepe Yönetimin Ulusllararası Tecrübesi / Bütün Yöneticilerin Toplam Tecrübesi.

PDIO: Psychic Dispersion of International Operations: İhracat Yapılan Ülke Sayıs1 / Pazardaki Toplam Ülke Sayısı.

Uluslararasılaşma derecesi literatürde, Uluslararasılaşma derecesi skalası haricinde, uluslararasılaşma indeksleri olarak Çokulusluluk İndeksi ve Çokulusluluk Faaliyetleri Yayılma İndeksi olarak ta kullanılabilmektedir (Dörrenbächer, 2000: 122). Bu indeksler:

- UNTAC tarafindan (1995)'te kullanılan, Transnationality Index (Çok Ulusluluk İndeksi)

- Ietto-Gilles (1998)’te kullanılan, Transnational Activities Spread Index (Çok Ulusluluk Yayılma İndeksi) 
- Sullivan (1994)'te kullanılan Degree of Internationalization Scale (Uluslararasılaşma Derecesi Skalası) gibi indekslerdir.

Tablo 1. Uluslararasılaşma İçin Kullanılan İndikatörler (Dörrenbächer, 2000: 122)

\begin{tabular}{|c|c|c|}
\hline $\begin{array}{l}\text { Çokulusluluk İndeksi } \\
\text { (UNTAC 1995) }\end{array}$ & $\begin{array}{l}\text { Çokulusluluk Faaliyetleri } \\
\text { Yayllma Indeksi (Ietto - } \\
\text { Gilles, 1998) }\end{array}$ & $\begin{array}{l}\text { Uluslararasılaşma Derecesi } \\
\text { Skalast (Sullivan, 1994) }\end{array}$ \\
\hline $\begin{array}{l}\text { Yabancı Satışların, Toplam } \\
\text { Satışlara Oranı }\end{array}$ & $\begin{array}{l}\text { Yabancı Satışların, Toplam } \\
\text { Satışlara Oranı }\end{array}$ & $\begin{array}{l}\text { Yabancı Satışların, Toplam Satışlara } \\
\text { Oranı }\end{array}$ \\
\hline $\begin{array}{l}\text { Yabancı Varlıkların, Toplam } \\
\text { Varlıklara Oranı }\end{array}$ & $\begin{array}{l}\text { Yabancı Varlıkların, Toplam } \\
\text { Varlıklara Oranı }\end{array}$ & $\begin{array}{l}\text { Yabancı Varlıkların, Toplam } \\
\text { Varliklara Oranı }\end{array}$ \\
\hline $\begin{array}{l}\text { İhracat Çalışanları Sayısının, } \\
\text { Toplam Çalışanlara Oranı }\end{array}$ & $\begin{array}{l}\text { İhracat Çalışanları Sayısının, } \\
\text { Toplam Çalışanlara Oranı }\end{array}$ & $\begin{array}{l}\text { Yabancı Bağlı İştiraklerin, Toplam } \\
\text { Bağlı İştiraklere Oranı } \\
\text { Üst Düzey Yöneticilerin Uluslararas } \\
\text { Deneyimi } \\
\text { Uluslararası Operasyonların Fiziksel } \\
\text { Dağıllımı }\end{array}$ \\
\hline
\end{tabular}

\section{3. İșletme Performansı}

İşletme performansı, "işletmenin genel stratejik amaçlarının yanı sıra satış ve pazar payındaki büyüme ve karlılıkla ilgili organizasyonel hedeflere ulaşılması" olarak tanımlanır (Hult ve diğerleri, 2004: 430 - 431). Bu anlamda bir iş sisteminin performansı, belirli bir zaman dilimi sonundaki çıktısı ya da çalışmasının sonucu olarak belirtilebilir. Bu sonuç, işletme misyonunun ve/veya amacının yerine getirilmesi derecesi şeklinde algılanmalıdır (Şimşek, 2009: 175). İşletme performansı için literatürde kullanılan birçok parametre mevcuttur. $\mathrm{Bu}$ çalışmada ise işletme performansının belirlenmesinde hem sübjektif hem de objektif performans değişkenleri kullanılmıştır. Bunun için geniş bir literatür taraması yapılarak performans ile ilgili değişkenler belirlenmiştir. Literatürde en sık kullanılan işletme performansı göstergeleri ve bunların kullanıldığ1 çalışmalardan önemli olanlar şunlardır. Bunlar dışında kalan bazı performans göstergeleri ise diğerlerine benzer şekilde oluşturulmuştur. Satışlar (Ciro) (Erramilli, 1996; Li ve diğerleri, 2009); Pazar payı artışı (Sökmen, 2006; Bausch ve Krist, 2007); Karlılık (Kar) (Chiao vd. 2008); Yerel satışlar (Rättich, 2010; Rutihinda, 2008; Eren, 2006); Uluslararası satışlar Rättich (2010) ve bunlara benzer şekilde belirlenen diğer sübjektif işletme performansı ise Büyüme hızı, Yatırımlar, Yerel satışların karlılı̆gı, Uluslararası satışların karlılığı, İhracat yapılan ülke sayısı, İhracat satışları dır. Bu sübjektif performans ölçülerine ek olarak objektif işletme performansı için oluşturulan ve Fortune 500 listesinde yer alan hazır verilerden hesaplanan göstergeler ise şu şekilde sıralanabilir. Satışların geriye dönüş oranı $($ ROS $)=$ Net Kar / Satışlar; Yatırımların geriye dönüş oranı $(\mathrm{ROI})=$ (Yatırımların Getirisi - Yatırımların Maliyeti) / Yatırımların Maliyeti; Öz kaynakların getirisi oranı $(\mathrm{ROE})=$ Net Gelir / Hissedarların Öz Kaynakları; Varlıkların geriye dönüş oranı $(\mathrm{ROA})=$ Net Kar $/$ Aktifler

\section{Metodoloji}


Araştırmanın bu bölümünde araştırmanın hipotezleri ve modeli ile birlikte araştırmanın metodolojisine ilişkin bilgilere yer verilmiştir.

\subsection{Araştırmanın Amacı ve Kapsamı}

$\mathrm{Bu}$ çalışma, genel olarak işletmelerin Uluslararasılaşma derecesi üzerinde durmaktadır. $\mathrm{Bu}$ kapsamda çalışma uluslararasılaşma derecesinin işletme performansı üzerindeki etkilerini araştırmayı amaçlamaktadır. Bu çalışmanın amaçlarını daha açık bir şekilde sıralamak gerekirse:

- Uluslararasılaşma derecesinin sübjektif işletme performansı üzerindeki etkilerini belirlemek,

- Uluslararasılaşma derecesinin objektif işletme performansı üzerindeki etkilerini belirlemektir.

$\mathrm{Bu}$ çalışma bir alan çalışması ile desteklenerek yukarıda belirtilen amaçlara ulaşılmaya çalışılacaktır. Belirlenen amaçlar doğrultusunda araştırmanın hipotezleri ve modeli oluşturulup toplanacak verilerle hipotezler test edilecektir. Çalışma, işletmelerin uluslararasılaşma derecelerinin işletme performansına olan etkilerini belirleyerek bu konularda literatüre katkı amacıyla ve işletmeler için faydalı bilgiler içeren sonuçlar çıkarmayı hedeflemektedir.

\subsection{Ana Kütle ve Örneklem Seçimi}

$\mathrm{Bu}$ çalışmanın ana kütlesini Türkiye'de uluslararası alanda faaliyetlerini sürdüren büyük ölçekli işletmeler oluşturmaktadır. Fortune 500 Türkiye listesi alan çalışmasına uygun olduğu için seçilmiştir. Bu listede 2011, 2012 ve 2013 yılları olmak üzere üç yıl üst üste bu listede yer alan ve en az ihracat faaliyetleri ile de olsa uluslararası pazarlarla ilgisi bulunan 258 uluslararası işletme tespit edilmiş ve bu işletmeler araştırmanın alan çallş̧ması kapsamında değerlendirilmiştir.

\subsection{Araştırmanın Hipotezleri ve Modeli}

Uluslararasılaşma derecesi ile işletme performansı ilişkisi oluşturmaktadır. Burada uluslararasılaşma derecesinin işletme performansına pozitif anlamda etki ettiği düşüncesi hâkimdir. İşletmelerin uluslararasılaşma derecesinin, sübjektif ve objektif işletme performanslarına etkilerini araştırmak üzere yapılan literatür taraması sonucunda bazı çalışmalara ulaşılmıştır. Literatürde direkt olarak uluslararasılaşma derecesinin sübjektif işletme performansı üzerindeki etkilerini araştıran bir çalışmaya rastlanmamıştır ancak uluslararasılaşma derecesinin işletme performansının farklı parametreleri üzerinde bir çok çalışmaya rastlanmıştır. Örnegin, Hitt vd. (1997), Riahi ve Belkaoui (1998), Gomes ve Ramaswamy (1999)'in çalışmalarında uluslararasılaşma derecesi ile işletme performansı (varlıkların geri dönüşümü) üzerinde pozitif etki belirlenmiştir. Literatürde ulaşılan bu çalışmalardan yola çıkılarak oluşturulan ve uluslararasılaşma derecesinin sübjektif işletme performansı üzerindeki etkisini araştıran ilk hipotez şu şekildedir.

H1: Uluslararasılaşma derecesi, sübjektif işletme performansını pozitif etkilemektedir. Grant, (1987)'in çalışmasında uluslararasılaşma derecesi olarak FSTS'nin objektif işletme performans göstergeleri olan Satışlar, Karlılık, ROE ve ROS üzerinde pozitif yönde bir etkiye sahip olduğu bulunmuştur. Grant, (1988) başka bir çalışmada ise uluslararasılaşma derecesi olarak FSTS'nin objektif işletme performansı göstergesi olan ROA üzerinde pozitif yönde bir etkiye sahip olduğunu bulmuşlardır. Daniels ve Bracker, (1989), çalışmalarında uluslararasılaşma derecesi olarak FSTS ve FATA'nın ROS ve ROA üzerinde pozitif bir etkiye 
sahip olduğunu bulmuştur. Ek olarak Riahi ve Belkaoui, (1996) uluslararasılaşma derecesi olarak FSTS'nin objektif işletme performansı göstergesi olan ROA üzerinde pozitif yönde bir etkiye sahip olduğunu bulmuştur. Literatürdeki bu bulgular 1şı̆̆ında, uluslararasılaşma derecesinin objektif işletme performansı üzerindeki etkilerini araştırmak üzere aşağıdaki H2 hipotezi oluşturulmuştur.

H2: Uluslararasılaşma derecesi, objektif işletme performansını pozitif etkilemektedir.

$\mathrm{Bu}$ çalışma, genel olarak işletmelerin uluslararasılaşma derecesi üzerinde durmaktadır. $\mathrm{Bu}$ kapsamda çalışma üç boyut içermektedir. Bunlar:

- Uluslararasılaşma derecesi,

- $\quad$ Sübjektif işletme performans1,

- $\quad$ Objektif işletme performansı.

Çalışma bu üç boyut arasındaki ilişkiler üzerine kurulmuş ve uluslararasılaşma derecesi ve sübjektif ve objektif işletme performansı arasındaki ilişkileri araştırmaktadır. Bu ilişkiler ve hipotezler doğrultusunda oluşturulmuş model Şekil 1'de gösterilmektedir.

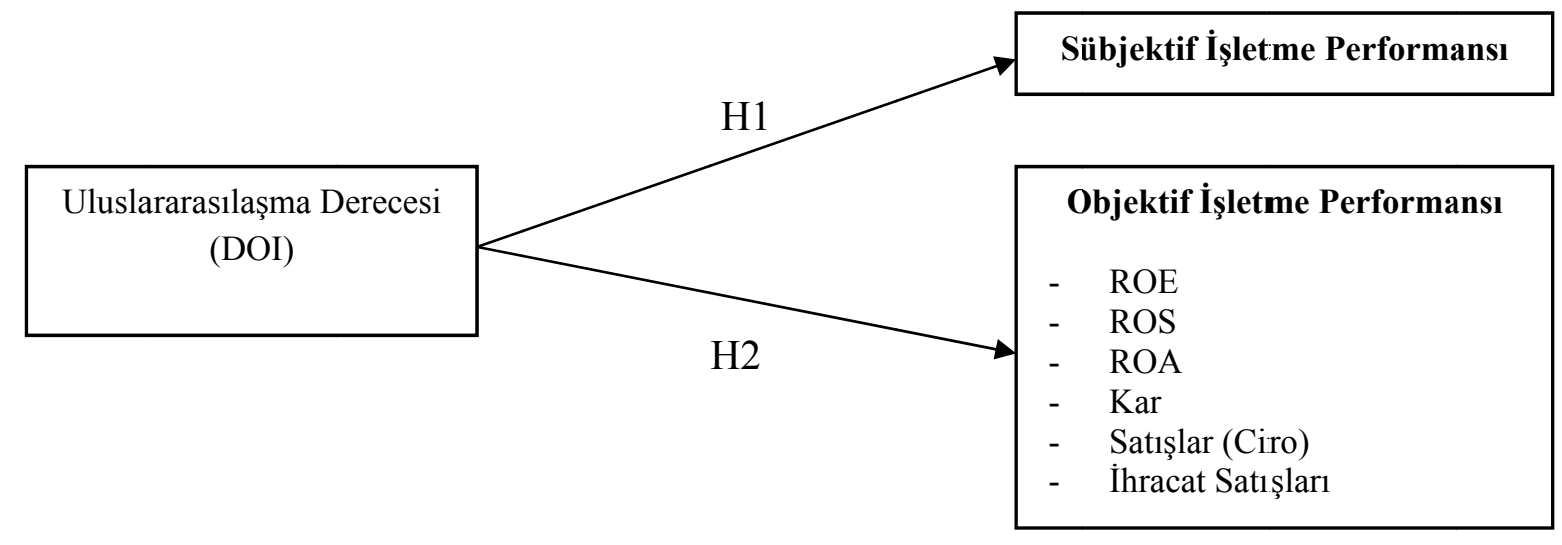

Şekil 1. Araştırmanın Modeli: Uluslararasılaşma Derecesi, Sübjektif İşletme Performansı ve Objektif İşletme Performansı Arası İlişskiler

\subsection{Araştırmanın Prosedürü, Verilerin Toplanması ve Geri Dönüşüm Oranı}

Araştırmada veri toplama yöntemi olarak anket kullanılmıştır. Anketlerin uygulanacağı işletmeler Fortune 500 Türkiye listesinde yer alan işletmelerden seçilmiştir ve araştırmada ana kütle olarak seçilen işletmelerin finansal bilgileri üç yıllık ortalamaları dikkate alınarak hesaplanmış ve objektif işletme performansı göstergeleri olarak analize hazır hale getirilmiştir.

Araştırmada kullanılan anket soruları literatürdeki çeşitli kaynaklardan elde edilen anket sorularının derlenmesi ve kullanılan değişkenlerden uyarlanması şeklinde oluşturulmuştur. Anket dört bölümden oluşmaktadır. Anketin birinci bölümünde işletmelerin karakteristiklerini (temel özellikleri) ölçmeye yönelik sorulardan, ikinci bölümde, işletmelerin uluslararasılaşma derecesini ölçmeye yönelik sorulardan, üçüncü bölümde ise işletmelerin performanslarını ölçmeye yönelik sorulardan oluşmaktadır. Anketin birinci ve ikinci bölümündeki sorular, açık uçlu sorulardan, üçüncü bölümünde ise işletmelerin sübjektif performanslarını ölçen 5'li Likert ölçeği ile hazırlanmış önermelerden oluşmaktadır. Ayrıca anket sorularında yer almamasına rağmen objektif işletme performansı ile ilgili olarak Fortune 500 listesinden elde edilen performans göstergeleri (ROE, ROS, ROA, Kar, Satışlar (toplam satışlar) ve İhracat Satışları) de her işletme için ayrı ayrı hesaplanmıştır ayrıca Bu parametrelerden, Kar, Satışlar ve İhracat Satışları değişkenleri analizlerde logaritmaları alınarak kullanılmıştır. Elde edilen bütün veriler SPSS 16.0 istatistik paket programında analiz edilmiştir. 
Çalışma sonucunda anketin geri dönüş sayısı 258 işletmeden 114 olarak gerçekleşmiştir diğer bir ifadeyle geri dönüş oran $\% 44,18$ 'dir. Ancak geri dönen anketlerden 11 'i başka bir deyişle \% 4,26's1 kullanılamayacak (mükerrer, eksik doldurulmuş ve isimsiz) durumda olup, anket geri dönüşündeki net ve kullanılabilir anket sayısı 103 başka bir ifadeyle \% 39,92 olarak gerçekleşmiştir.

\section{Bulgular}

Araştırmanın bu bölümünde alan çalışması sonucu elde edilen verilerin analizlerine ve analizlere ait yorumlara yer verilmiştir.

\subsection{Araştırmanın Güvenirlilik Analizi Sonuçları}

Çalışmanın alan çalışması kısmında kullanılan ve anket formunda yer alan, güvenirlilik analizi yapmaya uygun olan sübjektif işletme performansına ait olan ölçeklerin güvenirlilik analizi sonucu Cronbach's Alpha değeri $\alpha=0,930$ olarak bulunmuştur. Nunnally (1978)'e göre alfa değeri 0,70 veya üzerinde bir değere sahip $(0,70 \leq \alpha \leq 1)$ ise ölçek güvenilir kabul edilmektedir. Diğer taraftan güvenirlilik analizi yapmaya uygun olmayan işletme karakteristikleri, uluslararasılaşma derecesi ve objektif işletme performansı değişkenleri için bu analiz yapılmamıştır.

\subsection{Araştırmanın Temel Değişkenleri}

Analizlerin bu bölümünde, işletmelerin sahip olduğu karakteristikler ile ilgi olarak yapılmış tanımlayıcı istatistiklere yer verilmiştir ve bu bulgular, tablolar halinde özetlenerek yorumlanmıştır. Tablolar incelendiğinde dikkat edilecek önemli bir husus bazı tablolarda frekansların 103'ten az olduğudur. Bunun en önemli nedeni çalışmaya katılan, katılımcıların bazı soruları yanıtlama konusunda çekimser kalmalarıdır.

\subsection{1. İşletmelerin Faaliyet Yıllarına İlişkin Bulgular}

Çalışmaya katılan işletmelerin vermiş olduğu yanıtlar incelendiğinde; katılımcıların \% 23,30'u 41-50 yıl arasinda, \% 23,30'u 31- 40 yil arasinda, \% 16,50'si 21-30 yıl arasinda, \% 25,25 'i 51 yıl ve daha uzun süredir, \% 7,77'si ise 11-20 yıl arasında, ayrıca işletmelerin \% 3,88'i 10 y1ldan daha az faaliyet sürelerine sahip olduklarını ifade etmişlerdir. Tablo 2 genel olarak değerlendirildiğinde araştırmaya katılan işletmelerin büyük bir çoğunluğunun faaliyet sürelerinin 31-50 yıl arasında olduğu görülmektedir.

Tablo 2. İşletmelerin Faaliyet Y1lları Değişkenine Göre Dağılımı

\begin{tabular}{|c|c|c|}
\hline Faaliyet Yullart & Frekans $(f)$ & Yüzde (\%) \\
\hline $\begin{array}{l}0-10 \mathrm{y} 1 \mathrm{l} \\
11-20 \mathrm{y} 1 \mathrm{l} \\
21-30 \mathrm{y} 1 \mathrm{l} \\
31-40 \mathrm{y} 1 \mathrm{l} \\
41-50 \mathrm{y} 1 \mathrm{l} \\
51-60 \mathrm{y} 1 \mathrm{l} \\
61-70 \mathrm{y} 1 \mathrm{l} \\
71-80 \mathrm{y} 1 \mathrm{l} \\
81-90 \mathrm{y} 1 \mathrm{l} \\
\text { Toplam }\end{array}$ & $\begin{array}{l}4 \\
8 \\
17 \\
24 \\
24 \\
14 \\
7 \\
4 \\
1 \\
\mathbf{1 0 3}\end{array}$ & $\begin{array}{l}3,88 \\
7,77 \\
16,50 \\
23,30 \\
23,30 \\
13,60 \\
6,80 \\
3,88 \\
0,97 \\
\mathbf{1 0 0}\end{array}$ \\
\hline
\end{tabular}




\subsection{2. İşletmelerin Faaliyette Bulundukları Sektörlere İlişkin Bulgular}

Araştırmaya katılan işletmeler faaliyette bulundukları sektörler açısından Tablo 3'de incelendiğinde; işletmelerin \% 19,42'sinin tarım ve gıda, \% 16,50'sinin petrol, petrol türevleri ve kimya, \% 14,60'ının elektrikli aletler, makine ve ekipman, \% 12,62'sinin tekstil, \% 5,82'sinin yapı ve inşaat, \% 2,90'ının ticaret ve perakendecilik, \% 2,90'ının otomobil, yedek parça ve ekipmanları, \% 4,84'ünün medikal ve ilaç, basım, yayım ve medya, cam ve cam ürünleri gibi farklı sektörlerde faaliyette bulunduklarını ifade ettikleri görülmektedir. Tablo 3 sektörlerin dağılımı açısından incelendiğinde ve araştırmaya katılan işletmelerin daha çok tarım ve gida, maden, metal, toprak, orman ve orman ürünleri, tekstil vb. sektörlerde faaliyette bulundukları görülmektedir.

Tablo 3. İşletmelerin Faaliyette Bulundukları Sektörlere Göre Dağılımı

\begin{tabular}{lll}
\hline Sektörler & Frekans $(\boldsymbol{f})$ & Yüzde (\%) \\
\hline Petrol, petrol türevleri ve kimya & 17 & 16,50 \\
Tekstil & 13 & 12,62 \\
Maden, metal ve toprak & 17 & 16,50 \\
Tarım ve gıda & 20 & 19,42 \\
Ticaret ve perakendecilik & 3 & 2,90 \\
Otomobil, yedek parça ekipmanları & 3 & 2,90 \\
Orman ve orman ürünleri & 4 & 3,90 \\
Yapı ve inşaat & 6 & 5,82 \\
Elektrikli aletler, makine ve ekipman & 15 & 14,60 \\
Diğer (Medikal ve İlaç, Basım Yayım ve Medya, Cam ve Cam & & \\
Ürünleri) & 5 & 4,84 \\
Toplam & $\mathbf{1 0 3}$ & $\mathbf{1 0 0}$ \\
\hline
\end{tabular}

\subsection{3. İşletmelerin Büyüklüğüne (Çalışan Sayıları) İlişkin Bulgular}

Çalışmaya katılan işletmeler, büyüklüklerini temsil eden çalışan sayıları açısından, Tablo 4'te incelendiğinde; işletmelerin \% 51,46'sının 1000'den az, \% 26,21'inin 1001 - 2000, \% 9,71'inin 2001 - 3000, \% 3,88'inin 3000 - 4000, \% 8,74'ünün ise 5001 ve üzeri sayıda çalışan sayısına sahip olduklarını ifade ettikleri görülmektedir. Tablo 4 çalışmaya katılan işletmeler açısından genel olarak değerlendirildiğinde; işletmelerin büyük bir çoğunluğunun 2000'den az çalışan sayısına sahip oldukları dikkati çekmektedir, buna karşın çalışmaya katılan işletmelerin çok az bir kısmının 2000'den fazla çalışan sayısına sahip olduğu görülmektedir.

Tablo 4. İşletmelerin Çalışan Sayıları Değişkenine Göre Dağılımı

\begin{tabular}{lll}
\hline Çalışan sayıları & Frekans $(\boldsymbol{f})$ & Yüzde (\%) \\
\hline $1-1000$ & 53 & 51,46 \\
$1001-2000$ & 27 & 26,21 \\
$2001-3000$ & 10 & 9,71 \\
$3001-4000$ & 4 & 3,88 \\
4001 ve üzeri & 9 & 8,74 \\
Toplam & $\mathbf{1 0 3}$ & $\mathbf{1 0 0}$ \\
\hline
\end{tabular}

\subsection{4. İşletmelerin Sahip Olduğu Uluslararası Deneyime İlişkin Bulgular}


Araştırmaya katılan işletmeler, Tablo 5'de uluslararası deneyimleri açısından incelendiğinde; işletmelerin \% 27,7'sinin 11-20 yılları arası, \% 26,7'sinin 21-30 yılları arası, \% 17,9'unun 110 yılları arası, \% 7,9'unun 41-50 yılları arası bir süredir ve \% 7,9'unun ise 51 y1ldan daha fazla bir süredir uluslararası deneyime sahip olduklarını ifade ettikleri görülmektedir. Tablo 5 genel olarak değerlendirildiğinde; işletmelerin büyük bir çoğunluğunun 40 yıldan daha az uluslararası deneyime sahip oldukları, bununla birlikte işletmelerin çok az kısmının ise 40 yıldan daha fazla uluslararası deneyime sahip oldukları görülmektedir.

Tablo 5. İşletmelerin Sahip Olduğu Uluslararası Deneyim Değişkenine Göre Dağılımı

\begin{tabular}{lll}
\hline Uluslararasi deneyim & Frekans $(\boldsymbol{f})$ & Yüzde (\%) \\
\hline $1-10$ y1l aras1 & 18 & 17,9 \\
$11-20$ y1l aras1 & 28 & 27,7 \\
$21-30$ y1l aras1 & 27 & 26,7 \\
31 - 40 y1l aras1 & 12 & 11,9 \\
$41-50$ y1l aras1 & 8 & 7,9 \\
51 y1l - üzeri & 8 & 7,9 \\
Toplam & $\mathbf{1 0 1}$ & $\mathbf{1 0 0}$ \\
\hline
\end{tabular}

\subsection{5. İşletmelerin Uluslararası Operasyonlarının Fiziksel Dağılımına İllişkin Bulgular}

Araştırmaya katılan işletmeler, uluslararası operasyonlarının fiziksel dağılımları açısından Tablo 6'da incelendiğinde; işletmelerin \% 32'sinin $21-40$ arası, \% 27,2'sinin $1-20$ aras1, \% 15,5'inin 41 - 60 aras1, \% 12,6'sinin $61-80$ aras1, \% 6,8'inin 81-100 aras1 ve \% 5,81'inin ise 101 ve daha fazla sayıda ülkede faaliyet gösterdiklerini ifade ettikleri görülmektedir. Tablo 6 genel olarak değerlendirildiğinde işletmelerin genellikle 80 ve daha az ülkede faaliyette bulundukları ve çok az sayıda işletmeninde 81 ülkeden fazla ülkede faaliyette bulundukları görülmektedir.

Tablo 6. İşletmelerin Uluslararası Operasyonlarının Fiziksel Dağılımı Değisşkenine Göre Dağılımı

\begin{tabular}{lll}
\hline Uluslararası operasyonların fiziksel dağılımı (Ülke Sayısı) & Frekans (f) & Yüzde (\%) \\
\hline $1-20$ arası & 28 & 27,2 \\
$21-40$ arası & 33 & 32 \\
$41-60$ arası & 16 & 15,5 \\
$61-80$ arası & 13 & 12,6 \\
$81-100$ aras1 & 7 & 6,8 \\
101 ve üzeri & 6 & 5,81 \\
Toplam & $\mathbf{1 0 3}$ & $\mathbf{1 0 0}$ \\
& & \\
\hline
\end{tabular}


Tablo 7. Uluslararasılaşma Derecesi, Sübjektif ve Objektif İşletme Performansı Korelasyon Analizi Sonuçları

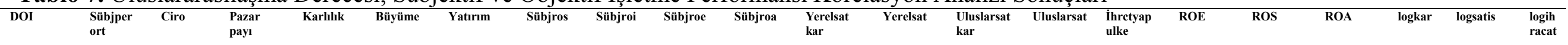

\begin{tabular}{|c|c|c|c|c|c|c|c|c|c|c|c|c|c|c|c|c|c|c|c|c|c|c|}
\hline & 1 & & & & & & & & & & & & & & & & & & & & & \\
\hline $\begin{array}{l}\text { Sübjper } \\
\text { Ort. }\end{array}$ &, $315^{* *}$ & 1 & & & & & & & & & & & & & & & & & & & & \\
\hline Ciro &, $318^{* *}$ & ,691** & 1 & & & & & & & & & & & & & & & & & & & \\
\hline $\begin{array}{l}\text { Pazar } \\
\text { payı }\end{array}$ &, $317^{* *}$ &, $721^{* *}$ &, $614^{* *}$ & 1 & & & & & & & & & & & & & & & & & & \\
\hline karllık &, $231^{*}$ &, $825^{* *}$ &, $559 * *$ & ,664** & 1 & & & & & & & & & & & & & & & & & \\
\hline Büyüme &, $317^{* *}$ &, $767^{* *}$ & ,638** & ,683** &, $750 * *$ & 1 & & & & & & & & & & & & & & & & \\
\hline Yatırım & 139 &, $745^{* *}$ &, $597 * *$ & ,629** & ,659** & ,688** & 1 & & & & & & & & & & & & & & & \\
\hline Sübjros & 160 & ,790** & ,439** &, $422 * *$ &, $573 * *$ & ,449** & ,476** & 1 & & & & & & & & & & & & & & \\
\hline Sübjroi & 166 & ,798** &, $453 * *$ &, $377^{* *}$ &, $574 * *$ &, $427^{* *}$ &, $518^{* *}$ &, $744^{* *}$ & 1 & & & & & & & & & & & & & \\
\hline Sübjroe & ,213* &, $813^{* *}$ & ,459** &, $454^{* *}$ & ,659** & ,444** &, $545^{* *}$ &, $725^{* *}$ &, $867^{* *}$ & 1 & & & & & & & & & & & & \\
\hline Sübjroa & ,237* &, $812^{* *}$ &, $494 * *$ &, $450 * *$ &, $646 * *$ &, $515^{* *}$ &, $578 * *$ &, $753^{* *}$ &, $829 * *$ &, $904 * *$ & 1 & & & & & & & & & & & \\
\hline $\begin{array}{l}\text { Yerelsat } \\
\text { kar }\end{array}$ & 167 &, $647^{* *}$ & 177 &, $361^{* *}$ &, $528^{* *}$ &, $367^{* *}$ & ,295** &, $416 * *$ & ,495** &, $508^{* *}$ &, $501 * *$ & 1 & & & & & & & & & & \\
\hline Yerelsat & 165 &, $598^{* *}$ &, $368 * *$ &, $477^{* *}$ &, $385^{* *}$ &, $462 * *$ & ,356** &, $333^{* *}$ &, $343 * *$ &, $328 * *$ &, $311 * *$ &, $645^{* *}$ & 1 & & & & & & & & & \\
\hline $\begin{array}{l}\text { Uluslarsat } \\
\text { kar }\end{array}$ & 196 & ,698** &, $263 * *$ & ,379** &, $526 * *$ &, $381^{* *}$ &, $353 * *$ &, $504^{* *}$ &, $624 * *$ &, $557^{* *}$ &, $501^{* *}$ &, $586 * *$ &, $376^{* *}$ & 1 & & & & & & & & \\
\hline Uluslarsat & ,225* &, $691^{* *}$ &, $353^{* *}$ &, $497^{* *}$ &, $484^{* *}$ &, $457^{* *}$ &, $429 * *$ &, $423^{* *}$ &, $461^{* *}$ &, $474^{* *}$ & ,488** &, $454 * *$ & ,439** &, $752^{* *}$ & 1 & & & & & & & \\
\hline İhretyapulke &, $427 * *$ &, $538^{* *}$ &, $370 * *$ &, $408^{* *}$ &, $317^{* *}$ &, $451^{* *}$ &, $290 * *$ &, $377^{* *}$ &, $374^{* *}$ &, $337^{* *}$ & ,298** & ,240* &, $341^{* *}$ & ,398** &, $516 * *$ & 1 & & & & & & \\
\hline ROE & 153 & 192 & ,229* & 148 & 119, & 140 & 189 & 119 & 149 & ,214* & ,199* & 100 & ,241* & 179 & ,204* & ,059 & 1 & & & & & \\
\hline ROS & ,004 & ,043 & ,014 &,- 029 &,- 024 &,- 040 &,- 007 & ,096 & 158 & ,082 & 101 & 014 & ,075 & 089 & 095 & ,009 & ,268** & 1 & & & & \\
\hline ROA & 129 & 113 & 186 & 137 & , 070 & ,077 & 124 & ,080 & 139, & 150 & 157, & 070 & 117 & 087 & 142 & ,015 & ,606** &, $742 * *$ & 1 & & & \\
\hline Logkar & ,085 & 111 & 184 & 067 & 174 & 139 & 142 & ,042 & ,090 & 113 & 165 & ,037 & ,083 & ,071 & 176 & ,047 &, $308 * *$ & ,513** & ,495** & 1 & & \\
\hline Logsatis & ,080 &, $291^{* *}$ & ,209* & ,232* & ,300** & ,313** & ,249* & 103 &, $260 * *$ & ,230* &, $280 * *$ & ,236* & ,211* & 171 & 158 & 101 & ,216* & ,033 & 142 & ,242* & 1 & \\
\hline Logihracat & ,224* & 181 & 133 & ,205* & ,202* & ,280** & ,245* & 122 & 137 & ,132 & 184 & 013 & ,092 & ,084 & 174 & 179 &, $272^{* *}$ & ,050 & 120 & ,034 &, $317 * *$ & 1 \\
\hline
\end{tabular}

$* *: \mathrm{p}<0.01, *: \mathrm{p}<0.05$ 
Tablo 7 Uluslararasılaşma derecesi ile sübjektif işletme performansı (ort.) ve objektif işletme performansı arasındaki ilişkiler açısından incelendiğinde;

- Uluslararasılaşma derecesi ile sübjektif işletme performansı (ort.) arasında pozitif yönlü ve istatistiksel olarak anlamlı bir ilişki belirlenmiştir $(r=0,315 ; p<0,01)$.

- Uluslararasılaşma derecesi ile objektif işletme performansı göstergelerinden olan ihracat satışları arasında pozitif yönlü ve istatistiksel olarak anlamlı bir ilişski belirlenmiştir $(r=0,224$; $\mathrm{p}<0,05)$.

Uluslararasılaşma derecesinin işletme performansı üzerindeki etkilerini araştırmak için oluşturulan hipotezlerden ilki "H1" hipotezi olan ve uluslararasılaşma derecesinin, sübjektif işletme performansı üzerindeki etkilerini araştıran analiz (Tablo 8). İkinci ise "H2" olan ve uluslararasılaşma derecesinin objektif işletme performans değişkenleri (ROE, ROS, ROA, KAR, Satışlar, İhracat Satışları) üzerindeki etkisini araştıran diğer analizlerdir (Tablo 9).

Regresyon analizinde uluslararasılaşma derecesi bağımsız değişken, sübjektif işletme performansı ise bağımlı değişken olarak alınmıştır. Analizde bağımlı değişken olarak alınan sübjektif işletme performansı faktörlerinin ortalamaları alınarak tek bir faktör olarak kullanılmıştır. Tablo 8 incelendiğinde, uluslararasılaşma derecesinin, sübjektif işletme performansını pozitif yönde ve istatistiksel açıdan anlamlı $(\beta=0,315 ; \mathrm{p}<0,01)$ bir şekilde etkilediği belirlenmiştir $(\mathrm{F}=9,934)$. Tablo 8 'de yer alan düzeltilmiş $\mathrm{R}^{2}$ değeri 0,089 olup buna göre uluslararasılaşma derecesi, işletme performansını düşük bir oranda da olsa $\% 8,9$ oranında açıklamaktadır. $\mathrm{Bu}$ yüzden araştırmanın birinci hipotezi olan " $H 1$ : Uluslararasılaşma derecesi, sübjektif işletme performansını pozitif etkilemektedir" hipotezi kabul edilmiştir.

Tablo 8. Uluslararasılaşma Derecesi ve Sübjektif İşletme Performansı Regresyon Analizi Sonucu

\begin{tabular}{lllllll}
\hline Băğımsız Değişken & $\boldsymbol{\beta}$ & $\boldsymbol{T}$ & $\boldsymbol{p}$ & $\boldsymbol{R}^{2}$ & Düzeltilmiş $\boldsymbol{R}^{2}$ & $\boldsymbol{F}$ \\
\hline Uluslararasılaşma Derecesi &, $315^{* *}$ & 3,152 &, 002 &, 089 &, 089 & $9,934^{* *}$
\end{tabular}

Bağımlı değişken: Sübjektif işletme performansı, ${ }^{*}$ * $<<0,01,{ }^{*} \mathrm{p}<0,05$

Uluslararasılaşma derecesinin, objektif işletme performansı göstergelerinden olan ihracat satışları üzerinde pozitif yönlü ve istatistiksel olarak anlamlı $(\beta=0,224 ; p<0,05)$ bir etkiye sahip olduğu belirlenmiştir $(\mathrm{F}=5,342)$. Buna göre regresyon modelli objektif işletme performansı göstergelerinden olan ihracat satışları açısından desteklenmektedir (Tablo 9). Tablo 9'da yer alan düzeltilmiş $\mathrm{R}^{2}$ değeri 0,041 olup buna göre uluslararasılaşma derecesi, ihracat satışlarını çok düşük bir oranda da olsa \% 4,1 oranında açıklamaktadır. Ancak uluslararasılaşma derecesinin diğer objektif işletme performansı göstergeleri (ROE, ROS, ROA, Kar, Satışlar) üzerinde herhangi bir etkisi bulunamamıştır. Bu yüzden çalışmanın ikinci hipotezi olan "H2: Uluslararasılaşma derecesi, objektif işletme performansını pozitif etkilemektedir" hipotezi kısmen kabul edilmiştir. 
Tablo 9. Uluslararasılaşma Derecesi ve Objektif İşletme Performansı Regresyon Analizi Sonuçları

\begin{tabular}{|c|c|c|c|c|c|c|}
\hline $\begin{array}{l}\text { Bağımsız } \\
\text { Değişken }\end{array}$ & $R O E$ & $\operatorname{ROS}$ & $R O A$ & $K A R$ & SATIŞLAR & $\begin{array}{l}\text { IHRACAT } \\
\text { SATISSLARI }\end{array}$ \\
\hline Uluslararasılassma Derecesi & ,153 &, 004 &, 129 &, 085 &, 080 & $224 *$ \\
\hline $\boldsymbol{R}^{2}$ & ,023 &, 000 & ,017 & ,007 & ,006 & ,050 \\
\hline Düzeltilmiş $R^{2}$ &, 014 &,- 010 &, 007 &,- 003 &,- 003 & ,041 \\
\hline$F$ & 2,409 &, 001 & 1,706 &, 713 & ,646 & $5,342 *$ \\
\hline
\end{tabular}

Bağımlı değişkenler: ROE, ROS, ROA, KAR, Satışlar, İhracat Satışları, **p<0,01, *p<0,05

Buna göre "H1: Uluslararasılaşma derecesi, sübjektif işletme performansını pozitif etkilemektedir" hipotezi kabul edilmiştir. "H2: Uluslararasılaşma derecesi, objektif işletme performansını pozitif etkilemektedir" hipotezi ise kısmen kabul edilmiştir.

\section{Sonuç ve Tartışma}

$\mathrm{Bu}$ çalışmanın odak noktasını, uluslararasılaşma ve uluslararasılaşma derecesi oluşturmaktadır. Çalışmanın teorik kısmını takip eden alan çalışması kısmında Uluslararasılaşma derecesinin sübjektif ve objektif işletme performansı üzerindeki etkisini belirlemek amaçlanmıştır. Çalışmada sunulan değişkenler arasında oluşturulan hipotezler SPSS 16.0 istatistik paket programı aracılığıyla regresyon analizi yöntemi ile analiz edilmiştir.

Analiz sonucunda uluslararasılaşma derecesinin, işletme performansı üzerindeki etkisi tekli doğrusal regresyon analizi ile araştırılmış ve uluslararasılaşma derecesinin sübjektif işletme performansını pozitif yönde etkilediği (Tablo 8) ayrıca uluslararasılaşma derecesinin objektif işletme performanslarından olan yanlızca ihracat satışları üzerinde pozitif bir etkisinin olduğu belirlenmiştir (Tablo 9). Yapılan analizler sonucunda H1 hipotezi kabul edilmiş ve $\mathrm{H} 2$ hipotezi ise kısmen kabul edilmiştir. Hipotezlerin kabul durumları tablo 10 'da gösterilmiştir.

Tablo 10. Araştırmada Yer Alan Ana Hipotezlerin Kabul / Red Durumu

\begin{tabular}{lr}
\hline Hipotezler & Kabul Durumu \\
\hline H1: Uluslararasılaşma derecesi sübjektif işletme performansını pozitif etkilemektedir & Kabul \\
H2: Uluslararasışaşa derecesi, objektif işletme performansını pozitif etkilemektedir &
\end{tabular}

Kismen Kabul

Yapılan analizler sonucunda uluslararasılaşma derecesinin işletme performansına etkileri değerlendirildiğinde; analiz sonucunda elde edilen sonuca benzer olarak Lu ve Beamish (2001) çalışmasında uluslararasılaşmanın işletme performansı üzerinde pozitif bir etkisinin olduğunu belirlemiştir. Hsu (2003) çalışmasında uluslararasılaşmanın işletme performansını tam olarak desteklediği sonucuna ulaşmışlardır. Öte yandan uluslararasılaşma derecesinin objektif işletme performansına etkileri açısından değerlendirildiğinde; uluslararasılaşma derecesi, objektif işletme performansı göstergelerinden olan "ihracat satışları"'nı pozitif etkilemektedir. Bu sonuç ile paralel olarak Sökmen (2006) çalışmasındla uluslararasılaşma derecesinin, ihracat performansı (objektif işletme performansı) üzerinde pozitif etkisinin olduğunu bulmuştur. Araújo (2008) çalışmasında uluslararasılaşma derecesinin işletmenin finansal performansı üzerinde pozitif bir etkiye sahip olduğunu bulmuştur. Şahin (2006) çalışmasında işletmelerin uluslararası faaliyetlerine başladıktan sonra işletme performanslarında bir artış olduğunu belirlemiştir. Sieler (2008) çalışmasında uluslararasılaşma derecesinin işletme performansını pozitif etkilediği sonucuna ulaşmışlardır. Xuemei (2011) çalışmasında uluslararasılaşma derecesinin işletme performansı üzerinde 
pozitif yönlü bir etki bulmuştur. Bazı çalışmalarda uluslararasılaşma ile iişletme performansı arasında pozitif ilişki bulunmasına rağmen Özkandemir (2004) çalışmasında uluslararasılaşma derecesinin işletme performansı üzerinde herhangi bir etkisinin olmadığı sonucuna ulaşmıştır.

Diğer taraftan uluslararasılaşma derecesinin diğer objektif işletme performansı göstergeleri olan ROE, ROS, ROA, KAR ve Satışlar üzerinde herhangi bir etkiye sahip olmadığı belirlenmiştir. Grant, (1987) çalışmasında uluslararasılaşma derecesi olarak FSTS'nin objektif işletme performans göstergeleri olan Satışlar, Karlılık, ROE ve ROS üzerinde pozitif yönde bir etkiye sahip olduğu; Grant, Jammine ve diğerleri, (1988) başka bir çalışmada ise uluslararasılaşma derecesi olarak FSTS'nin objektif işletme performansı göstergesi olan ROA üzerinde pozitif yönde bir etkiye sahip olduğu; Daniels ve Bracker, (19189), çalışmalarında uluslararasılaşma derecesi olarak FSTS ve FATA'nın ROS ve ROA üzerinde pozitif bir etkiye sahip olduğunu; Riahi ve Belkaoui, (1996) uluslararasılaşma derecesi olarak FSTS'nin objektif işletme performansı göstergesi olan ROA üzerinde pozitif yönde bir etkiye sahip olduğunu bulmuş olmasına rağmen bu çalışmada literatürdeki sonuçların aksine sonuçlarla karşılaşılmıştır.

Ancak araştırma da, genel olarak literatürde yer alan çalışmaların sonuçlarına paralel olarak uluslararasılaşma derecesinin işletme performansı üzerinde pozitif bir etkiye sahip olduğu bulunmuştur. Bulunan bu sonuç işletmelerin uluslararasılaşmalarının performanslarına da önemli derecede etki ettiğinin bir göstergesidir. Bu yüzden, performanslarını artırmak isteyen işletmeler uluslararasılaşmaya daha çok önem vermelidirler.

Bu çalışmanın konusu ile ilgili olarak, daha sonra yapılacak olan çalışmalar için bir takım öneriler sunulması gerekirse;

- Bundan sonraki çalışmalarda İSO 500 gibi farklı kurum ve kuruluşların yayınlamış olduğu listeler deki işletmelerde alan çalışması kapsamında değerlendirilebilir,

- İkinci olarak Fortune 500 ve diğer listelerde yer alan işletmelerle ilgili olarak sunulmuş olan hazır veriler kullanılarak farklı hesaplama ve analiz yöntemleri kullanılabilir ve belki de bu sayede farklı sonuçlar elde edilebilir,

- Bundan sonraki çalışmalar belli sektörlere odaklanılarak, sektörel bazda da yapılabilir,

- Gelecekte yapılacak olan çalışmalara farklı modeller ortaya koyulup test edilebilir. 


\section{REFERENCES}

- AGARWAL, S. ve RAMASWAMI, S.N., 1992. "Choice of Foreign Market Entry Mode: Impact of Ownership, Location and Internationalization Factors", Journal of International Business Studies, s. 1-27

- AKGEMCİ, T., 2013. Stratejik Yönetim, Gazi Kitapevi, Ankara, 783s.

- ALTINTAŞ, H. ve ÖZDEMIR, E., 2006. "İhracat İşletmelerinin Uluslararasılaşması: Türkiye'de Faaliyet Gösteren KOBİlere Yönelik Bir Araştırma”, Sosyal Bilimler Dergisi, 2006/1, ss.183-204.

- ARAÚJO, J.F., 2008. “The Impact of Internationalization on Firm's Performance- A Qualitative Study of Portuguese SMEs”, Yüksek Lisans Tezi, ISCTE Business School, Instituto Superior de Ciências do Trabalho e da Empresa, Portugal

- BAUSCH, A. ve KRIST, M., 2007. "The Effect of Context - Related Moderators on the Internationalization - Performance Relationship: Evidence from Meta - Analysis", Management International Review, 3, ss.319-347.

- BOAS, R.V. ve GONZÁLEZ, I.S., "Internationalization and Firm Performance: The S-Curve Hypothesis Under the Eurozone Context", Documentos De Trabajo, Nuevas Tendencias En Dirección De Empresas, Dt 15/07.

- CENGíz, E., GEGEZ, A.E., ARSLAN, M., PİRINTİ, S. ve TIĞLI, M., 2007. Uluslararası Pazarlara Giriş Stratejileri, Beta Basım Yayım Dağıtım, 221s.

- CHANG, J., 2011. "The Early and Rapid Internationalization of Asian Emerging MNEs", Competitiveness Review: An International Business Journal, 21, (2), ss.171187.

- CHEN H. ve HSU, C.W. 2010. “Internationalization, Resource Allocation and Firm Performance", Industrial Marketing Management, 39, ss.1103-1110.

- CHIAO, Y. ve YANG, K,Y,C., 2006. "Performance, Internationalization, and FirmSpecific Advantages of SMEs in a Newly - Industrialized Economy", Small Business Economics, 26, ss.475-492.

- CHIAO, Y., YEH, M. ve CHUANG, J., 2008. "Government Attitudes toward Internationalization, and SMEs' Performance", Academy of Management, Annual Meeting, ss.1-40

- CUPTA, K., 2005. Contemporary Auditing, Tata McGraw - Hill Publishing Company, New Delhi, 1488s.

- DANIELS, J.D. ve BRACKER, J., 1989, "Profit Performance: Do Foreign Operations Make a Difference", Management International Review, 29, 1, ss:46-56.

- DANIELS, J.D. ve RADEBAUGH, L.H., 1989. International, Business Environments and Operations, Fifth Edition, Addison - Wesley Publishing Company, U.S.A., 716s.

- DÖRRENBÄCHER, C., 2000. "Measuring Corporate Internationalisation A Review of Measurement Concepts and Their Use", Intereconomics, Mayıs / Haziran, ss.119 126.

- EBNETH, O. ve THEUVSEN L., 2006. The Relationship Between Business Internationalization and Financial Performance of Stock- Listed Brewing Groups, International Food and Agribusiness Management Association 16th Annual World Forum, Symposium and Case Conference, June 10-13, Buenos Aires, Argentina.

- ElANGO, B., 2006. "An Empirical Analysis of the Internationalization Performance Relationship Across Emerging Market Firms", Multinational Business Review, 14, (1), ss.21-44. 
- EREN, M.Ş., 2006. "Şirket Girişimciliğine Etki Eden Faktörler ve Şirket Girişimciliği İle İşletme Performansı İlişkisi Üzerine Bir Saha Araştırması", Doktora Tezi, Gebze İleri teknoloji Enstitüsü, Sosyal Bilimler Enstitüsü, İşletme Ana Bilim Dalı, Gebze.

- ERİŞ, E.D., 2008. "Lojistik Sektöründe Pazar Yönlü - Öğrenme Yönlü Olma ve Yenilikçiliğin İşletme Performansına Etkisi Üzerine Bir Araştırma”, Doktora Tezi, Dokuz Eylül Üniversitesi, Sosyal Bilimler Enstitüsü, İşletme Anabilim Dalı, İstanbul.

- ERKUTLU, H. ve ERYİ̈̆İT, S., 2001. "Uluslararasılaşma Süreci”, Gazi Üniversitesi, İktisadi ve İdari Bilimler Fakültesi Dergisi, 3, ss.149-164.

- ERRAMILLI, M.K., 1996. "Nationality and Subsidiary Ownership Patterns in Multinational Corporations". Journal of International Business Studies, 27, (2), ss.225-248.

- Fleury, M., BORINI, F.M., FleURY, A. ve OliVERIA, M. M., 2007. "Internationalization and Performance: A Comparison of Brazilian Exporters Versus Brazilian Multinationals, Economiae Gestao", Belo Horizonte, 7, (14), ss.1-178.

- GASTANAGA, V.M., NUGENT, J.B. ve PASHAMOVA, B., 1998. "Host Country Reforms and FDI Inflows: How Much Difference Do They Make ?", World Development, 26, (7), ss.1299-1314.

- GOMES, L. ve RAMASWAMY, K., 1999. "An Empirical Examination of the Form of the Relationship Between Multinationality and Performance". Journal of International Business Studie, 30, (1), ss.173 -187.

- GRANT M.R., JAMMINE, A.P. VE HOWARD T., 1988. "Diversity, diversifiction, and Profitability Among British Manaufacturing Companies, 1972 -1984”, Academy of Management Journal, 31,4, ss:771-801

- GRANT, R.M., 1987, "Multinationality and Performance Among British Manufacturing Companies”, Journal of International Business Studies, 18,3.ss.79-89.

- HITT, M.A., ROBERT E.H. ve HICHEON K., 1997. "International Diversification: Effects on Innovation and Firm Performance in Product - Diversified Firms", Academy of Management Journal, 40, (4), ss.767 - 98.

- HSU, C.C, 2003. "An Integrated Model of The Internationalization - Performance Relationship", Faculty of The Graduate School of Saint Louis University.

- HSU, C.C. ve BOGGS, D..J., 2003. "Internationalization and Performance: Traditional Measures and Their Decomposition", Multinational Business Review, 11, (3), ss.2349.

- HSU, C.C., 2006. "Internationalization and Performance: The S-Curve Hypothesis and Product Diversity Effect", Multinational Business Review, 14, (2), ss.29-46

- HULT, T., HURLEY, R. ve KNIGHT, G., 2004. "Innovativeness:Its Antecedents and Impact on Business Performance", Industrial Marketing Management, 33, ss. 429438.

- IETTO-GILLIES, G. "Assessing The Degree of Internationalization Some Conceptual Issues", http://www.aueb.gr/deos/EIBA2002.files/PAPERS/W72.pdf

- KARABAĞ, S.F., 2008. "Strateji ve Endüstrinin Firma Performansina Etkisi: Türkiye'nin Öncü Sanayi İşletmeleri Üzerine Bir Araştırma”, Doktora Tezi, Çukurova Üniversitesi, Sosyal Bilimler Enstitüsü, İşletme Anabilim Dalı, Adana.

- KARACAOĞLU, K., 2006. “İşletmelerin Rekabet Üstünlüğü Anlayışlarını Etkileyen Ögelerin Endüstri Temelli ve Kaynak Temelli Bakış Açısına Göre Belirlenmesi: Kayseri İlinde Bir Araştırma", Çukurova Üniversitesi, İktisadi ve İdari Bilimler Dergisi, 10, (2), ss.1-22. 
- KENNELLY, J.J. ve LEWIS, E.E., 2004. "Degree of Internationalization and Environmental Performance: Evidence From U.S. Multinationals", Multinationals, Environment and Global Competition Research in Global Strategic Management, volume 9, ss.23-41.

- LAVIE, D. ve MILLER, S.R., 2008. “Alliance Portfolio Internationalization and Firm Performance”, Organization Science, 19, (4), ss.623-646.

- LAWRENCE, S.W. ve LUOSTARINEN, R., 1988. "Internationalization: Evolution of A Concept Journal of General Management", The Brybrooke Press Limited, 14, (2), ss. 156-161.

- LEE, C.F. ve LEE, A.C., 2006. Encyclopedia of Finance, Springer Siences Business Media, Inc., USA. 773s.

- LI, J. J., ZHOU, K. Z. ve SHAO, A. T., 2009. “Competitive Position, Managerial Ties, and Profitability of Foreign Firms in China: An Interactive Perspective". Journal of International Business Studies, 40,(2), ss.339-352.

- LU, J.W. ve BEAMISH, P.W., 2000. "Internationalization \& Performance: Exporting vs. FDI", ASAC-IFSAM, Conference Montreal, ss.1-11.

- LU, J.W. ve BEAMISH, P.W., 2001. The Internationalization and Performance of SMEs, Strategic Management Journal, 22, ss.565-586.

- LU, J.W. ve BEAMISH, P.W., 2002. The Internationalization and Growth of SMEs, ASAC, Winipeg, Manitoba. ss.86- 96.

- MAJOCCHI, A. ve ZUCCHELLA, A., 2003. "Internationalization and Performance Findings from a Set of Itallian SMEs", International Small Business Journal, 21, (3), ss.249-268.

- MUTLU, E.C., 2008. Uluslararası İşletmecilik, Beta Yayınları, İstanbul, 464s.

- NIELSEN, S., 2010. "Top Management Team Internationalization and Firm Performance", Management International Review, 50, ss.185-206.

- NUNALLY, J. C., 1978. Psychometric Theory, McGraw-Hill, New York, 701s.

- OLMOS, M.F., 2011. "The Determinants of Internationalization: Evidence from the Wine Industry", Applied Economic Perspectives and Policy, 33, (3), ss.384 401.

- ÖZKANDEMİR, Ö., 2004. “Küreselleşme Sürecindeki KOBİ'lerde Uluslararasılaşma ve Performans", Beykent Üniversitesi, Sosyal Bilimler Enstitüsü, Yüksek Lisans Tezi, Istanbul.

- PAZARDAKİ ÜLKE SAYISI, http://tr.wikipedia.org/wiki/\%C3\%9Clkeler_listesi, (25.12.2013).

- PEŠKOVÁ, M.B., 2006. "Internationalization of Swiss SMEs: State, Performance \& Influencing Factors", Doctorate Thesis, University of Fribourg, Faculty of Economics and Social Sciences, Fribourg, Switzerland.

- RÄTTICH, G., CLARK, K. ve HARTMANN, E., 2010. "Performance Measurement and Antecedents of Early Internationalizing Firms: A Systematic Assessment", The University of Texas at San Antonio, College of Business, Working Paper Series, ss.148

- RIAHI-BELKAOUI, A., 1996, "Internationalization, Diversification Strategy and Ownership Structer: Implications for French MNE Performance", International Business Review, 5, 4, ss:367-376.

- RIAHI- BELKAOUI, A., 1998. "The Effects of the Degree of Internationalization on Firm Performance". International Business Review, 7, (3), ss.315- 21.

- RIECK, O., CHEAH, J., LAU, A. ve LEE, S. 2004. "The Relationship Between the Degree of Internationalization and Firm Performance in the Telecommunication 
Industry". ITS. Europe 16th European Regional Conference, Port, Portugal, September 4-6, ss. 1-30

- RUTIHINDA, C., 2008. "Factors Influencing The Internationalization of Small and Medium Size Enterprises", International Business \& Economics Research Journal, December, 7, (12), ss.45-54.

- ŞAHIN, E., 2006. "Uluslararasılaşmanın Firma Finansal Performansına Etkisi”, İstanbul Teknik Üniversitesi, Fen Bilimleri Enstitüsü, Endüstri Mühendisliği Ana Bilim Dalı, Yüksek Lisans Tezi.

- SIELER, S., 2008. "Determinants of the Internationalization - Performance Relationship: An Empirical Examination of the Influence of Organizational and Contextual Variables", Dissertation Zur Erlangung Des Akademischen Grades Einer Doktors Der Wirtschaftswissenschaften An Der Universität Augsburg.

- ŞİMŞEK, M.Ş., 2009. İşletme Bilimine Giriş, Adım Matbaacılık ve Ofset, Konya, $415 \mathrm{~s}$.

- SÖKMEN, A.G., 2006. "Firma Kaynakları, İhracat Stratejileri ve Uluslararasılaşma Derecesi: Küçük ve Orta Boy İşletmeler Üzerine Bir Araştırma”, Yüksek Lisans Tezi, Çukurova Üniversitesi, Sosyal Bilimler Enstitüsü, İşletme Anabilim Dalı, Adana

- SUlliVAN, D., 1994. "Measuring The Degree of Internationalization of A Firm", Journal of International Business Studies, Second Quarter, ss.325-342.

- THOMAS, D.E. ve EDEN, L., 2004. "What is the Shape of the MultinationalityPerformance Relationship ?", Multinational Business Review, Vol. 12 Iss: 1, pp.89110

- WAHID, F., 2010. "Innovation - Performance Relationship. The Moderaing Role of the Degree of Internationalization on A Firm", University of Waterloo, Master of Applied Science in Management Sciences, Canada.

- WISMIARSI, T., 2008.'Internationalisation of Firms: Relationship Between Firms Characteristics, International Market Orientation and the Degree of Internationalisation", National Conference on Management Research, Makassar.

- XUEMEI, Y., 2011. Degree of Internationalization and Firm Performance, Evidence from China's State-owned Banks,IEEE

- ZHOU, L., WU, W. ve LUO, X., 2007. "Internationalization and the Performance of Born-Global SMEs: the Mediating Role of Social Networks", Journal of International Business Studies, 38, ss.673-690. 